\title{
PENGARUH UNIVERSAL DESIGN FOR LEARNING (UDL) BERBASIS SOCIAL LEARNING NETWORKS (SLN) TERHADAP HASIL BELAJAR MAHASISWA STKIP PGRI SITUBONDO
}

\author{
Beny Hari Firmansyah, Anselmus J.E. Toenlioe, Saida Ulfa \\ Universitas Negeri Malang \\ E-mail: Beny.harifirmansyah@gmail.com
}

\begin{abstract}
Abstrak. Penelitian ini merupakan penelitian eksperimen dengan menggunakan rancangan eksperimental, pretest \& posttest control group design. Terdapat dua kelompok dalam penelitian ini, yaitu kelompok eksperimen yang menerapkan perlakuan pembelajaran UDL berbasis SLN dan kelompok kontrol yang tidak menerapkan perlakuan. Subjek penelitian ini melibatkan mahasiswa sebanyak 45 orang di STKIP PGRI Situbondo yang mengambil mata kuliah Telaah Kurikulum. Data yang dikumpulkan dalam penelitian ini diolah dengan bantuan program SPSS for windows versi 22.0 dengan teknik analisis data paired sample t test untuk menguji hipotesis penelitian. Hasil penelitian menunjukkan bahwa terdapat perbedaan hasil belajar antara kelompok eksperimen $(78,00)$ yang diberi perlakuan pembelajaran UDL berbasis SLN dengan kelompok kontrol $(71,50)$ yang tidak diberi perlakuan. Hal ini juga dibuktikan dari hasil perhitungan menggunakan normalized gain diperoleh gain untuk kelompok eksperimen $(0,38)$ sedangkan kelompok kontrol $(0,12)$. Selisih rata-rata gain kelompok eksperimen dan kelompok kontrol adalah 0,38-0,12=0,26, dengan demikian dapat dikatakan bahwa pembelajaran UDL berbasis SLN efektif untuk meningkatkan hasil belajar mahasiswa. Dalam pengujian hipotesis menggunakan t test didapatkan hasil thitung sebesar 3,630 apabila dibandingkan dengan tabel sebesar 1,729 yang berarti thitung $>t_{\text {tabel }}(3,630>1,729)$, artinya dengan demikian $H_{1}$ diterima. Jadi kesimpulannya pembelajaran Universal Design for Learning berbasis Social Learning Networks berpengaruh terhadap hasil belajar secara signifikan.
\end{abstract}

Kata Kunci: Universal Design for Learning, Social Learning Networks, hasil belajar.

\section{PENDAHULUAN}

Evolusi dalam duni digital telah membawa perubahan yang besar dalam cara berpikir manusia. Informasi menjadi sebuah komoditas yang sangat penting bagi keberlangsungan hidup manusia. Manusia berusaha melakukan apapun untuk mendapatkan informasi, salah satunya dengan melakukan penggalian pada kepingan-kepingan data yang sangat besar yang berasal dari aktivitas manusia. Data tersebut sangat besar dan banyak secara kuantitas (volume), sangat cepat berubah/bertumbuh (velocity) dan hadir dalam beragam bentuk/format (variety). Istilah data yang besar lazim disebut dengan Big Data yang telah mengubah cara kita memahami dunia yang berdampak besar dan akan terus menciptakan riak melalui semua aspek kehidupan kita.

Dengan perkembangan data inilah Big Data muncul dan saat ini mulai berkembang. Penggunaannya pun semakin luas, hingga mencakup jejaring sosial (Social Networks). Seiring meluasnya 
pemanfaatan Social Networks (SN), muncullah aplikasi Social Learning Networks (SLN) sebagai salah satu bentuk pemanfaatan untuk pembelajaran di bidang pendidikan. Contoh platform yang dilengkapi SLN adalah Schoology (www.schoology.com), Edmodo (www.edmodo.com), Einztein (www.einztein.com), Remix Learning (www.remixlearning.com) dan Twiducate (www.twiducate.com).

\section{Social Learning Networks (SLN)} merujuk pada koneksi interpersonal melalui interaksi dengan tujuan utama untuk pengembangan pengetahuan atau dapat dikatakan dengan kata lain SLN merupakan penggabungan Social Networks dengan e-learning sehingga dapat dimanfaatkan untuk proses pembelajaran (Subiyantoro, 2013).

Penggunaan jejaring sosial dalam pendidikan formal perlu diterapkan karena dapat membantu pebelajar dalam belajar. Jejaring sosial dapat digunakan oleh para pebelajar dalam sebuah kolaborasi/diskusi yang dilaksanakan secara informal. Menurut Nurkamid, Dahlan, Susanto dan Khotimah (2011), fungsi dari jejaring sosial sudah berubah yang tadinya hanya sekedar media berbagi informasi (sharing information/status update) berubah menjadi kolaborasi dan berbagi informasi (collaborating and sharing). Kolaborasi dan berbagi informasi sangat diperlukan dalam pembelajaran karena setiap pebelajar memiliki pengetahuan dan pemahaman yang berbeda. Selain pengetahuan dan pemahaman, pebelajar juga memiliki karakteristik yang berbeda dalam belajar.

Kegiatan pembelajaran yang ada sekarang ini umumnya menyajikan presentasi materi yang sama untuk setiap peserta didik karena menganggap bahwa karakteristik semua peserta didik adalah homogen, padahal dalam kenataannya setiap peserta didik mempunyai karakteristik yang berbeda dalam belajar. Salah satu cara untuk menciptakan sebuah kegiatan pembelajaran yang dapat memfasilitasi perbedaan karakteristik peserta didik adalah Universal Design for Learning (UDL). UDL mampu untuk mengurangi kegagalan peserta didik dalam belajar dikarenakan proses pembelajaran yang diberikan pendidik akan disesuaikan dengan peserta didik agar proses belajar mengajar menjadi lebih mudah (Firmansyah, Toenlioe \& Ulfa; 2016).

UDL adalah sebuah konsep pendidikan atau pendekatan untuk merancang metode pembelajaran, bahan ajar, kegiatan pembelajaran, dan prosedur evaluasi dalam upaya untuk membantu individu dengan "perbedaan besar dalam kemampuan mereka untuk melihat, mendengar, berbicara, bergerak, membaca, menulis, memahami bahasa, hadir, mengatur, terlibat, dan mengingat" (Orkwis, 2003). UDL mengambil keuntungan dari perkembangan teknologi untuk mengakomodasi perbedaan peserta didik.

UDL dapat menggabungkan penggunaan bahan digital yang diimplementasikan ke dalam berbagai pengaturan pendidikan. Berbagai hasil penelitian telah menunjukkan bahwa bahan-bahan digital, seperti pidato otomatis untuk teks, memberikan pembelajaran yang sangat mendukung di kelas yang dirancang secara universal. Rancangan universal ini memberikan kesempatan yyang adil untuk peserta didik dalam belajar sehingga belajarnya lebih efektif dan hasil belajar peserta didik juga akan lebih maksimal.

Hasil belajar adalah kemampuan yang diperoleh siswa setelah melalui kegiatan belajar (Abdurrahman, 2003). Hasil belajar merupakan akibat yang ditimbulkan dari suatu proses pembelajaran siswa atau suatu yang menjadi milik siswa sebagai implikasi dari kegiatan belajar yang dilakukan. Proses pembelajaran dalam penelitian ini akan menggunakan UDL dan SLN untuk meningkatkan hasil belajar peserta didik.

Dalam penelitian ini UDL akan digabungkan dengan pemanfaatan jejaring 
sosial yang penggunaannya semakin luas. Jejaring sosial dalam pembelajaran (Social Learning Networks) akan memiliki daya tarik tersendiri bagi para pebelajar dikarenakan proses pembelajarannya yang dapat dilakukan dimana saja dan kapan saja serta isi materi yang disajikan akan disesuaikan dengan prinsip UDL sehingga pebelajar dapat memilih format materi yang sesuai dengan kebutuhannya untuk belajar. Pembelajaran ini akan menjadi efektif dikarenakan tidak terbatas waktu dan tempat serta belajar menjadi lebih mudah karena sesuai dengan gaya belajar sehingga hasil belajar peserta didik juga lebih maksimal.

Berdasarkan uraian diatas maka judul dari penelitian ini adalah "Pengaruh Universal Design for Learning (UDL) Berbasis Social Learning Networks (SLN) Terhadap Hasil Belajar..

Berdasarkan latar belakang diatas, maka rumusan masalahnya adalah "Bagaimana Pengaruh Universal Design for Learning (UDL) Berbasis Social Learning Networks (SLN) terhadap hasil belajar mahasiswa di STKIP PGRI Situbondo?".

Berdasarkan rumusan masalah diatas, maka hipotesis dari penelitian ini adalah Universal Design for Learning (UDL) berbasis Social Learning Networks (SLN) berpengaruh terhadap hasil belajar mahasiswa di STKIP PGRI Situbondo.

\section{KAJIAN TEORI \\ Universal Design for Learning (UDL)}

Pada dasarnya, UDL adalah sebuah konsep pendidikan atau pendekatan untuk merancang metode pembelajaran, bahan ajar, kegiatan pembelajaran, dan prosedur evaluasi dalam upaya untuk membantu individu dengan "perbedaan besar dalam kemampuan mereka untuk melihat, mendengar, berbicara, bergerak, membaca, menulis, memahami bahasa, hadir, mengatur, terlibat, dan mengingat" (Orkwis, 2003). UDL memberikan akses yang sama terhadap pembelajaran, tidak hanya akses yang sama terhadap informasi. Hal ini memungkinkan peserta didik untuk memilih metode yang paling tepat untuk mengakses informasi sementara guru memantau proses pembelajaran (Ohio State University Partnership Grant, 2010).

Salah satu kerangka kerja untuk menangani keragaman semua siswa dan menciptakan kurikulum yang fleksibel yang mendukung akses, partisipasi, dan kemajuan bagi semua peserta didik adalah Universal Design for Learning (UDL: Meyer \& Rose. 2000; Rose \& Meyer. 2002). Sebagai kerangka kerja untuk menciptakan kurikulum yang fleksibel, yang dalam pengaturan berbasis standar termasuk tujuan instruksional, metode, penilaian, dan bahan. UDL mengambil keuntungan dari teknologi inovatif untuk mengakomodasi perbedaan peserta didik. Kerangka kerja ini penting karena mencerminkan cara di mana siswa mengambil dan memproses informasi. Menggunakan kerangka kerja ini, pendidik dapat meningkatkan hasil untuk beragam peserta didik dengan menerapkan prinsipprinsip dibawah ini untuk pengembangan tujuan, metode pembelajaran, bahan kelas, dan penilaian. Penggunaan prinsip-prinsip ini mengarah ke hasil yang lebih baik bagi siswa karena mereka memberikan semua individu dengan kesempatan yang adil untuk belajar dengan meningkatkan akses konten.

UDL adalah perencanaan pembelajaran dan kerangka penyampaian yang dimaksudkan untuk meningkatkan akses bermakna dan mengurangi hambatan belajar bagi siswa dengan kebutuhan belajar yang beragam (Maya, Cecelia \& Sean; 2014). UDL sebagai desain pembelajaran material dan aktivitas untuk mengikuti tujuan pembelajaran sebagai capaian individu dengan taraf mengikuti tujuan pembelajaran sebagai capaian individu dengan taraf perbedaan di dalam kemampuannya untuk melihat, mendengar, berbicara, berbuat, membaca, menulis, memahami bahasa, kehadiran, 
mengorganisasikan, keterlibatannya dan keanggotaan di dalam kelompoknya.

UDL dapat menggabungkan penggunaan bahan digital dan diimplementasikan dalam berbagai pengaturan pendidikan. Penelitian telah menunjukkan bahwa bahan-bahan digital, seperti pidato otomatis untuk teks, memberikan pembelajaran yang kuat mendukung di kelas yang dirancang secara universal.

Dengan UDL, pendidik masih bisa memaksimalkan konsistensi tujuan pendidikan, dengan mengembangkan kurikulum yang fleksibel yang mendukung semua peserta didik (Hitchcock, 2002). UDL juga menyediakan untuk memberikan instruksi menggunakan berbagai metode pengajaran. Teknologi memberikan salah satu sarana untuk mengubah instruksi dan melibatkan siswa dalam format pembelajaran digital (Abdell \& Lewis, 2005).

\section{Social Networks (Jejaring Sosial)}

Social Networks (SN) adalah bentuk struktur sosial yang terdiri dari simpul-simpul yang saling terkait dan terikat oleh salah satu atau lebih tipe hubungan yang spesifik. Simpul-simpul yang dimaksudkan disini dapat berupa individu atau organisasi. Istilah jejaring sosial pertama kali diperkenalkan oleh Professor J.A. Barnes pada tahun 1954. Jejaring sosial merupakan sebuah sistem struktur sosial yang terdiri dari elemenelemen individu atau organisasi. Jejaring sosial ini akan membuat mereka yang memiliki kesamaan sosialitas, mulai dari mereka yang telah dikenal sehari-hari sampai dengan keluarga bisa berhubungan. Jejaring sosial juga dikatakan sebagai struktur yang dibentuk oleh orang-orang dan hubungan antara orang-orang, dengan pengaruh koneksi yang memungkinkan terjadinya interaksi dan pertukaran informasi.

Jejaring sosial merupakan situs dimana setiap orang bisa membuat web page pribadi, kemudian terhubung dengan teman-teman untuk berbagi informasi dan berkomunikasi. Jika media tradisional menggunakan media cetak dan media broadcast, maka media sosial menggunakan internet.

Saat teknologi internet semakin maju maka jejaring sosial pun ikut tumbuh dengan pesat. Kini untuk mengakses jejaring sosial facebook atau twitter misalnya, bisa dilakukan dimana saja dan kapan saja hanya dengan menggunakan mobile phone. Demikian cepatnya orang bisa mengakses media sosial mengakibatkan terjadinya fenomena besar terhadap arus informasi tidak hanya di negara-negara maju, tetapi juga di Indonesia.

\section{Social Learning Networks (SLN)}

Seiring meluasnya pemanaatan Social Networks (SN) khususnya facebook, muncullah aplikasi Social Learning Networks (SLN) sebagai salah satu bentuk pemanfaatan untuk pebelajaran di bidang pendidikan. Banyak pembelajaran online yang menggunakan jejaring sosial. Pembelajaran menggunakan jejaring sosial ini dilakukan karena pembelajarannya bisa dilakukan dimana saja dan kapan saja sesuai dengan kesepakatan pengajar dan pembelajarnya. Dikarenakan terbatasnya waktu yang ada di sekolah maupun kampus, pembelajaran menggunakan jejaring sosial merupakan solusi untuk mengatasi permasahalan-permasalahan tersebut.

Halimi (2011) mengatakan bahwa SLN bertujuan untuk mendorong penggunanya memiliki pengalaman baru dalam belajar menggunakan jejaring sosial yang telah dilengkapi konsep kepedulian sosial. Penggunaan jejaring sosial dalam pendidikan formal perlu diterapkan karena dapat membantu pebelajar dalam belajar. Jejaring sosial dapat digunakan oleh para pebelajar dalam sebuah kolaborasi/diskusi yang dilaksanakan secara informal. 


\section{Hasil Belajar}

Menurut Slameto (2003), belajar ialah suatu proses usaha yang dilakukan seseorang untuk memperoleh suatu perubahan tingkah laku yang baru secara keseluruhan, sebagai hasil pengalamannya sendiri dalam interaksi dengan lingkungannya. Dari kegiatan belajar inilah akan diperoleh hasil belajar. Hasil belajar ialah kemampuan yang dimiliki siswa setelah menerima pengalaman belajar. Sehingga dapat dikatakan orang yang belajar akan mengalami perubahan dan memperoleh suatu hasil belajarnya.

Hasil belajar yang telah dicapai siswa dikategorikan menjadi tiga bidang yaitu bidang kognitif, afektif dan psikomotorik (Sudjana, 2006). Oleh karena itu dapat disimpulkan bahwa hasil belajar adalah kemampuan-kemampuan yang dimiliki siswa setelah ia menerima pengalaman belajarnya atau dapat dikatakan bahwa hasil belajar adalah perubahan tingkah laku dalam diri siswa, yang diamati dan diukur dalam bentuk perubahan pengetahuan, tingkah laku, sikap dan keterampilan. Perubahan tersebut diartikan sebagai terjadinya peningkatan dan pengembangan ke arah yang lebih baik dari sebelumnya.

\section{METODE}

Rancangan dalam penelitian ini menggunakan rancangan experimental, pretest \& posttest control group design. Pemilihan desain penelitian eksperimen ini didasarkan atas pertimbangan bahwa: (1) rancangan penelitian eksperimen adalah metode paling ampuh untuk mengetahui hubungan sebab akibat antara dua variabel atau lebih, (2) penelitian eksperimen digunakan ketika peneliti ingin membangun kemungkinan sebab dan akibat antara variabel independen dan variabel dependen, (3) penelitian eksperimen ini digunakan untuk mencari pengaruh perlakuan tertentu terhadap yang lain dalam kondisi yang terkendalikan
(Gall \& Borg, 2003; Creswell, 2012; Sugiyono, 2016).

Penelitian ini dilakukan di STKIP PGRI Situbondo, semester IV jurusan Pendidikan Ekonomi tahun pelajaran 2016/2017. Populasi keseluruhan dalam penelitian ini adalah seluruh mahasiswa di STKIP PGRI Sittubondo, sedangkan populasi terjangkaunya adalah mahasiwa semester IV jurusan Pendidikan Ekonomi. Populasi ini terdiri dari 2 kelas yaitu Pendidikan Ekonomi IV A dan IV B. Sampel dalam penelitian ini diambil menggunakan teknik cluster random sampling, yaitu pengambilan sampel berdasarkan daerah populasi yang ditetapkan. Daerah populasi dalam penelitian ini adalah kelas Pendidikan Ekonomi IV A dan IV B yang akan dipilih secara random untuk dijadikan sampel. Kelas IV A akan dijadikan sebagai kelompok eksperimen sedangkan kelas IV B akan dijadik sebagai kelompok kontrol.

Teknik analisis data yang digunakan untuk penelitian ini adalah uji normalized gain (n-gain) dan paired sample $t$ test. Pengujian n-gain digunakan untuk mengetahui peningkatan skor pretest dan posttest. Gain menunjukkan peningkatan hasil belajar mahasiswa setelah pembelajaran dilakukan oleh dosen. Sedangkan, pengujian paired sample $t$ test dilakukan untuk mengetahui seberapa besar pengaruh UDL bebrbasis SLN terhadap hasil belajar. Dalam hal ini, uji statistik yang dilakukan menggunakan bantuan program SPSS for windows versi 22.0.

\section{HASIL DAN PEMBAHASAN}

Dari hasil perhitungan denggunakan normalized gain diperoleh gain untuk kelompok eksperimen sebesar 0,38 sedangkan gain kelompok kontrol adalah sebesar 0,12 . Nilai gain tersebut selanjutnya diinterpretasikan kedalam kriteria nilai gain, dan diperoleh bahwa efektifitas pembelajaran UDL berbasis SLN yang dilakukan pada kelompok 
eksperimen tergolong sedang, sedangkan efektifitas pada kelompok kontrol tanpa perlakuan tergolong rendah. Selisih ratarata nilai gain eksperimen dengan rata-rata nilai gain kontrol adalah $0,38-0,12=$ 0,26 , dengan demikian dapat dikatakan bahwa pembelajaran UDL berbasis SLN efektif untuk meningkatkan hasil belajar mahasiswa.

Setelah semua data diuji dengan menggunakan uji normalized gain kemudian dilakukan uji t. Uji $t$ dimaksudkan untuk melihat ada perbedaan atau tidak dari hasil belajar mahasiswa. Uji $\mathrm{t}$ yang dilakukan menggunakan analisis paired sample $t$ test yang dibantu oleh program SPSS for windows versi 22.0 menghasilkan bahwa tingkat signifikansi dari $t_{\text {tabel }}$ dengan ketentuan $\mathrm{df}=\mathrm{n}-1$ dan diperoleh tabel dari $\mathrm{df}=19$ adalah 1,729 kemudian uji $\mathrm{t}$ test didapatkan $\mathrm{t}_{\text {hitung }}>\mathrm{t}_{\text {tabel }}$ $(3,630>1,729)$. Artinya, terdapat perubahan yang signifikan antara hasil belajar mahasiswa sebelum dan sesudah proses pembelajaran UDL berbasis SLN.

Ditinjau dari hasil belajar mahasiswa, berdasarkan hasil uji hipotesis dari penelitian ini menunjukkan bahwa ada perbedaan yang signifikan untuk hasil belajar mahasiswa antara kelompok eksperimen yang diberi perlakuan pembelajaran UDL berbasis SLN dengan kelompok kontrol yang tidak diberi perlakuan. Temuan ini didasarkan pada hasil penghitungan data pretest dan posttest. Data pretest menunjukkan bahwa hasil belajar kelompok eksperimen dengan kelompok kontrol tidak berbeda secara signifikan, tetapi pada data posttest menunjukkan bahwa kelompok eksperimen mempunyai skor rata-rata hasil belajar yang lebih tinggi dibandingkan dengan skor rata-rata hasil belajar kelompok kontrol. Jika dibandingkan (selisih) antara kedua kelas ini, untuk peningkatan hasil belajar kelompok eksperimen lebih tinggi dari kelompok kontrol. Dengan temuan penelitian ini berarti bahwa kelompok eksperimen yang menerapkan pembelajaran UDL berbasis
SLN memberikan pengaruh lebih baik terhadap hasil belajar mahasiswa bila dibandingkan dengan kelompok kontrol yang tidak menerapkannya.

Berdasarkan hasil penelitian, menunjukkan bahwa pebelajar yang menerapkan pembelajaran ini memperoleh hasil belajar $(78,00)$ yang lebih besar dengan pebelajar yang tidak menerapkan pembelajaran ini $(71,50)$. Atau dapat dikatakan, pembelajaran UDL berbasis SLN membantu pebelajar untuk mendapatkan hasil belajar yang lebih baik.

\section{SIMPULAN DAN SARAN}

Berdasarkan paparan di atas, maka dapat disimpulkan hasil penelitian ini adalah pembelajaran Universal Design for Learning (UDL) berbasis Social Learning Networks (SLN) berpengaruh terhadap hasil belajar mahasiswa pada mata kuliah telaah kurikulum dengan melihat pada hasil perbandinan antara kelompok eksperimen dan kelompok kontrol.

Untuk penelitian lebih lanjut, disarankan pada mata kuliah yang berbeda seperti teknologi pembelajaran, teknologi informasi, dan yang lainnya di perguruan tinggi. Demikian pula disarankan pada sekolah menengah umum seperti kelas IPA, IPS, dan Bahasa atau di sekolah menengah kejuruan seperti kelas mesin, listrik, elektronika, sipil dan informatika untuk membandingkan dan menentukan apakah lokasi dan pada kelas yang berbeda diperoleh hasil yang sama. Berikutnya untuk penelitian lanjutan dapat pula melibatkan variabel-variabel lain seperti gaya belajar, sikap dan lainnya untuk melihat efektifitas pembelajaran UDL berbasis SLN. Demikian pula untuk hasil belajar dapat dilihat dari efisiensi, afektif atau interpersonal mahasiswa selain efektifitas hasil belajar. 


\section{DAFTAR PUSTAKA}

Abdell, M., \& Lewis, P. (2005). Universal Design for Learning: A Statewide Improvement Model for Academic Success. Information Technology and Disabilities, XI.

Abdurrahman, M. (2003). Pendidikan Bagi Anak Berkesulitan Belajar. Jakarta: Rineka Cipta.

Borg \& Gall. (2003). Education Research. New York: Allyn and Bacon.

Creswell, J.W. (2012). Education Research: Planning, Conducting, and Evaluating Quantitative and Qualitative Research. Boston: Person.

Firmansyah, Beny H. (2015). Pengembangan Blended Learning Berbasis Schoology. Prosiding Seminar Nasional Teknologi Pendidikan. 86-102. Malang: Prodi TEP UM.

Firmansyah, B.H., Toenlioe, A.J.E., \& Ulfa, S. (2016). Universal Design for Learning Sebagai Sarana Untuk Memfasilitasi Perbedaan Gaya Belajar Peserta Didik Dalam Belajar. Prosiding Seminar Nasional Teknologi Pembelajaran dan Psikologi Pendidikan. Malang: PPs UM.

Halimi, K., Seridi, H., \& Zucker, C.F. (2011). Solearn: Social Learning Network. International Conference and Computational Aspects of Social Network (CASoN). 130-135.

Hitchcock, C., Meyer, A., Rose, D., \& Jackson, R. (2002). Providing New Access to the General Curriculum: Universal Design for Learning. TEACHING Exceptional Children, $35,8-17$.
Kementerian Pendidikan dan Kebudayaan Universitas Negeri Malang. (2012). Pedoman Penulisan Karya Ilmiah: Skripsi, Tesis, Disertasi, Artikel, Makalah, Tugas Akhir, Laporan Penelitian. Edisi Kelima. Malang: UM.

Meyer \& Rose. (2000). Universal Design for Individual Differences. Educational Leadership.

Nielsen. (2011). Pertumbuhan Pengguna Ponsel di Indonesia Paling Tinggi. Retrieved 23 Oktober 2016, from http://www.agbnielsen.net/Uploads I

Indonesia/Nielsen_Newsletter_Mei 2011-Ind.pdf.

Nurkamid, M., Dahlan, M., Susanto, A., \& Khotimah, T. (2011). Pemanfaatan Aplikasi Jejaring Sosial Facebook Untuk Media Pembelajaran.

Kudus: Universitas Muria Kudus.

Orkwis. (2003). Universally Designed Instruction. ERIC/OSEP Digest. Arlington: ERIC Development Team.

Rose \& Meyer. (2002). Teaching Every Student in The Digital Age: Universal Design for Learning. Alexandria. VA: Association for Supervision and Curriculum Development.

Rose \& Meyer. (2006). A Practical Reader in Universal Design for Learning, Cambridge. MA: Harvard Education Press.

Slameto. (2003). Belajar dan FaktorFaktor yang Mempengaruhi. Jakarta: Rineka Cipta.

Southeast Asian Minister of Education Organization Regional Open 
Learning Centre. (2014). Draf

Buku Siswa Simulasi Digital.

Subiyantoro, E., Nugraha, H.C., Ratih,

C.K., \& Nosyrafil, R.R. (2013).

Simulasi Digital Jilid 1.

Kementrian Pendidikan dan

Kebudayaan.

Sudjana. (2006). Pengantar Evaluasi

Pendidikan. Bandung: Raja

Grafindo Persada.

Sudjana. (2010). Penilaian Hasil Proses

Belajar Mengajar. Bandung: PT

Remaja Rosdakarya.

Sugiyono. (2016). Metode Penelitian

Pendidikan: Pendekatan

Kuantitatif, Kualitatif, dan $R \& D$.

Bandung: Alfabeta. 